\title{
Improved Adaptive Hamiltonian Control Law for Constant Power Load Stability Issue in DC Microgrid: Case Study for Multiphase Interleaved Fuel Cell Boost Converter
}

\author{
Phatiphat Thounthong 1,2 $\mathbb{D}$, Pongsiri Mungporn 1,3,*(D), Babak Nahid-Mobarakeh ${ }^{4}$, Nicu Bizon ${ }^{5} \mathbb{D}$, \\ Serge Pierfederici ${ }^{6}$ and Damien Guilbert ${ }^{7, *(D)}$
}

1 Renewable Energy Research Centre (RERC), King Mongkut's University of Technology North Bangkok, 1518, Pracharat 1 Road, Wongsawang, Bangsue, Bangkok 10800, Thailand; phatiphat.t@fte.kmutnb.ac.th

2 Department of Teacher Training in Electrical Engineering, Faculty of Technical Education, King Mongkut's University of Technology North Bangkok, 1518, Pracharat 1 Road, Wongsawang, Bangsue, Bangkok 10800, Thailand

3 Thai-French Innovation Institute, King Mongkut's University of Technology North Bangkok, 1518, Pracharat 1 Road, Wongsawang, Bangsue, Bangkok 10800, Thailand

4 Department of Electrical and Computer Engineering, McMaster University, Hamilton, ON L8S 4L8, Canada; babak.nahid@mcmaster.ca

5 Department of Electronics, Computers and Electrical Engineering, Faculty of Electronics, Communications and Computers, The University of Pitesti, 110040 Pitesti, Romania; nicu.bizon@upit.ro

check for

updates

Citation: Thounthong, P.; Mungporn P.; Nahid-Mobarakeh, B.; Bizon, N.; Pierfederici, S.; Guilbert, D. Improved Adaptive Hamiltonian Control Law for Constant Power Load Stability Issue in DC Microgrid: Case Study for Multiphase Interleaved Fuel Cell Boost Converter. Sustainability 2021, 13, 8093. https://doi.org/10.3390/ su13148093

Academic Editor:

Thanikanti Sudhakar Babu

Received: 15 June 2021

Accepted: 17 July 2021

Published: 20 July 2021

Publisher's Note: MDPI stays neutral with regard to jurisdictional claims in published maps and institutional affiliations.

Copyright: (c) 2021 by the authors. Licensee MDPI, Basel, Switzerland. This article is an open access article distributed under the terms and conditions of the Creative Commons Attribution (CC BY) license (https:/ / creativecommons.org/licenses/by/ $4.0 /)$.
6 Laboratoire d'Energétique et de Mécanique Théorique et Appliquée (LEMTA), Université de Lorraine, CNRS, LEMTA, F-54000 Nancy, France; serge.pierfederici@univ-lorraine.fr

7 Groupe de Recherche en Energie Electrique de Nancy (GREEN), Université de Lorraine, GREEN, F-54000 Nancy, France

* Correspondence: pongsiri.m@tfii.kmutnb.ac.th (P.M.); damien.guilbert@univ-lorraine.fr (D.G.)

Abstract: The cascaded connection of power converters in a DC microgrid may cause instabilities. Indeed, power converters operating as external loads exhibit constant power load (CPL) behaviors. In this study, the design of the feedback controller of a multi-cell interleaved fuel cell (FC) step-up power circuit is based on the adaptive Hamiltonian control law. It includes two integral terms to confirm that there is no steady-state error in the DC bus voltage, and to guarantee the current balancing of each input inductor current. The design confirms that the desired equilibrium point is (locally) asymptotically stable by using the Lyapunov stability proof. The control approach is validated via digital simulations and experimental tests performed with a $2500 \mathrm{~W}$ FC converter supplied by an FC/reformer size of $2500 \mathrm{~W}$ and $50 \mathrm{~V}$.

Keywords: constant power load (CPL); electric car; DC microgrid; multi-cell interleaved boost circuit; fuel cell (FC); Lyapunov stability; Hamiltonian; passivity-based controller (PBC)

\section{Introduction}

While diesel engines generate electricity via thermal energy processes, fuel cell (FC) engines are electrochemical power sources that transform chemical energy directly into electrical energy; therefore, the losses in the thermal energy conversion process are removed with FCs, leading to higher electrical efficiency. FCs have a strong potential in DC microgrid applications (electric cars, shipboards, and more electric aircraft (MEA)) because of their benefits over conventional engines [1,2]. The chemical reactions occurring are different according to the type of FC. One type of FC is currently of interest for DC microgrid applications: a proton exchange membrane fuel cell (PEMFC) that operates at lower temperatures $\left(<90^{\circ} \mathrm{C}\right)$, enabling a quick start-up, low-exhaust emission, silent operation, lower maintenance costs, and relatively higher fuel efficiency $[3,4]$.

The FC output voltage is an unregulated DC voltage and it requires the use of a DC-DC converter for practical utilization. The boost converter (FC converter) is gener- 
ally chosen for its simplicity and low-cost to transform the low DC voltage provided by the FC to the DC bus connected to external loads, as shown in Figure 1. In high-power applications, and to reduce the FC input current ripple, multiphase boost converters featuring interleaving techniques have been proposed to interface the FC and the DC bus [4,5] (Figure 2). By utilizing interleaved techniques, the current stress of power electronics devices can be reduced, and the thermal distribution is enhanced. Multiphase boost converters can continue to operate even in the case of power switch failures due to their natural redundancy [4].

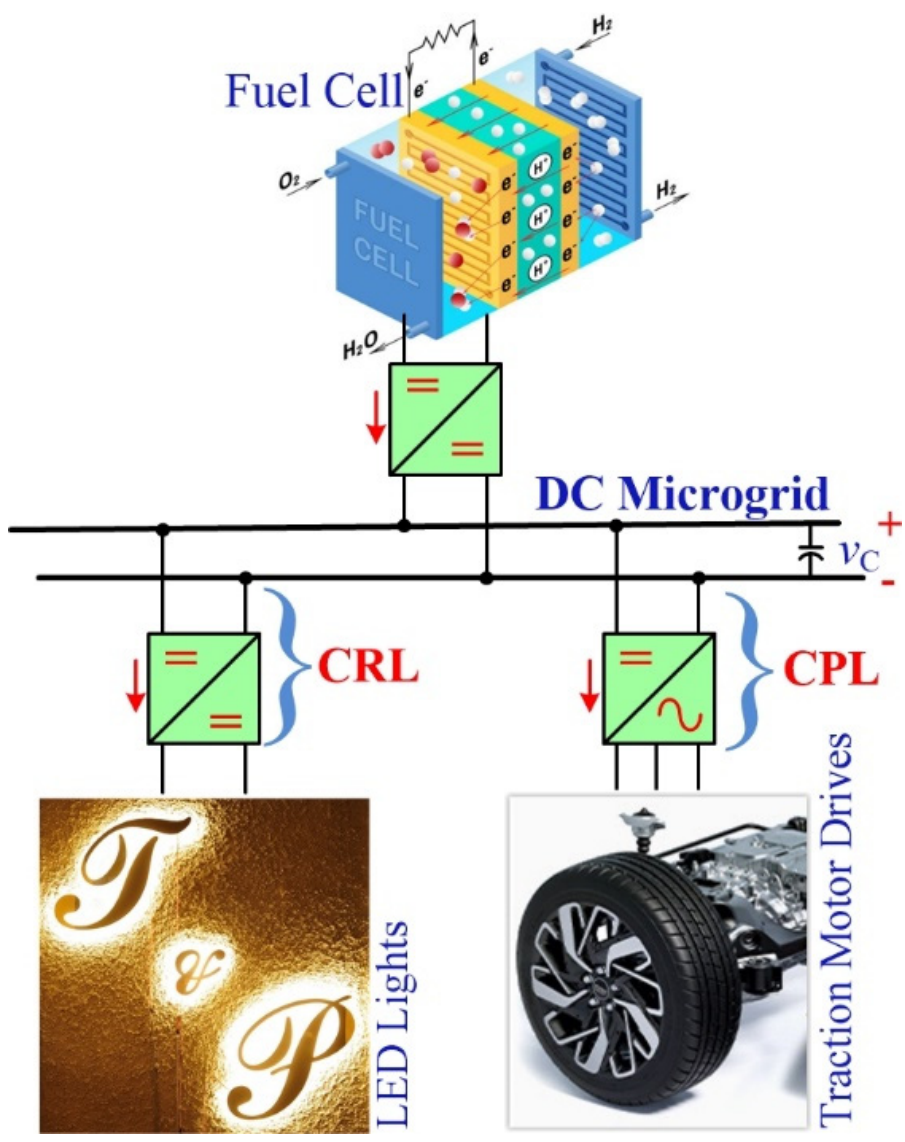

Figure 1. An FC energy source in dc microgrid.

More importantly, the constant resistive load (CRL) and/or constant power load (CPL) (see Figure 1) supplied by the DC bus are challenging issues in the DC microgrid, causing distinctive dynamic behaviors. For this reason, these issues have been studied in the literature. Under tight-speed/torque regulations with CPL association, the electric motor drive exhibits CPL characteristics at the DC bus [6,7]. In the case of CPLs, the instability of the DC bus connected to the power converters is a challenging issue. Indeed, this issue appeared during the 80s on a regional narrow gauge railway in Switzerland, where railcars were powered by DC motors. To address this issue, DC motors were substituted with induction motors fed by inverters. In this case, slight adjustments to the control structure of the inverter control solved the problem. The problem of the instability of the DC bus is strongly associated with the rated power of the converter system. With the increasing power of the converter system, the efficiency usually increases. Consequently, the inherent damping of the system declines. The system becomes more prone to this instability. The instability results in a smoothly increasing voltage oscillation that starts at a certain power level. By properly tuning the power level, it is possible to operate the system continuously with a certain limited voltage oscillation. On the other hand, increasing the power level immediately leads to a protective shutdown of the system. 


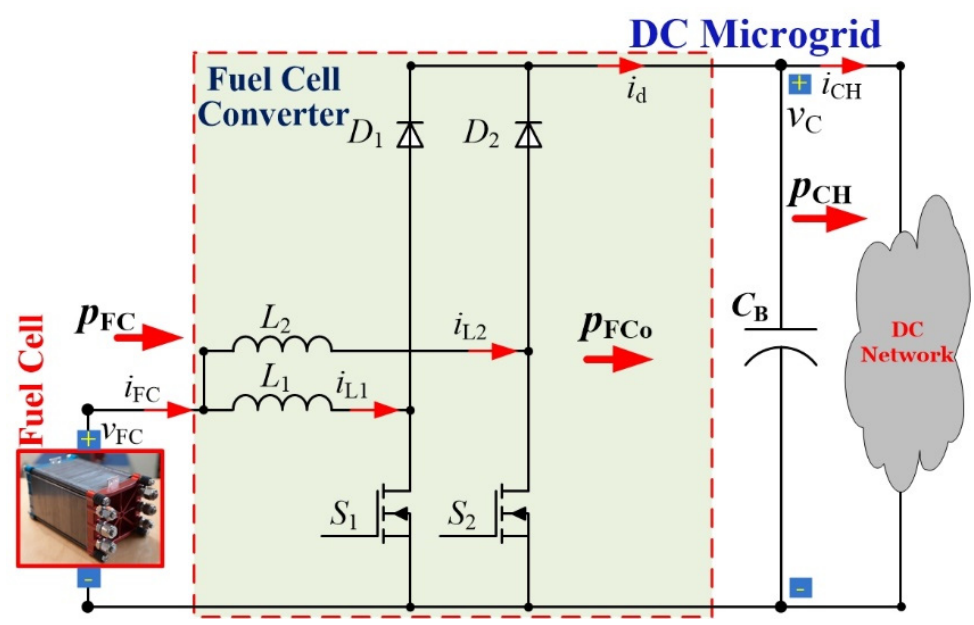

(a)

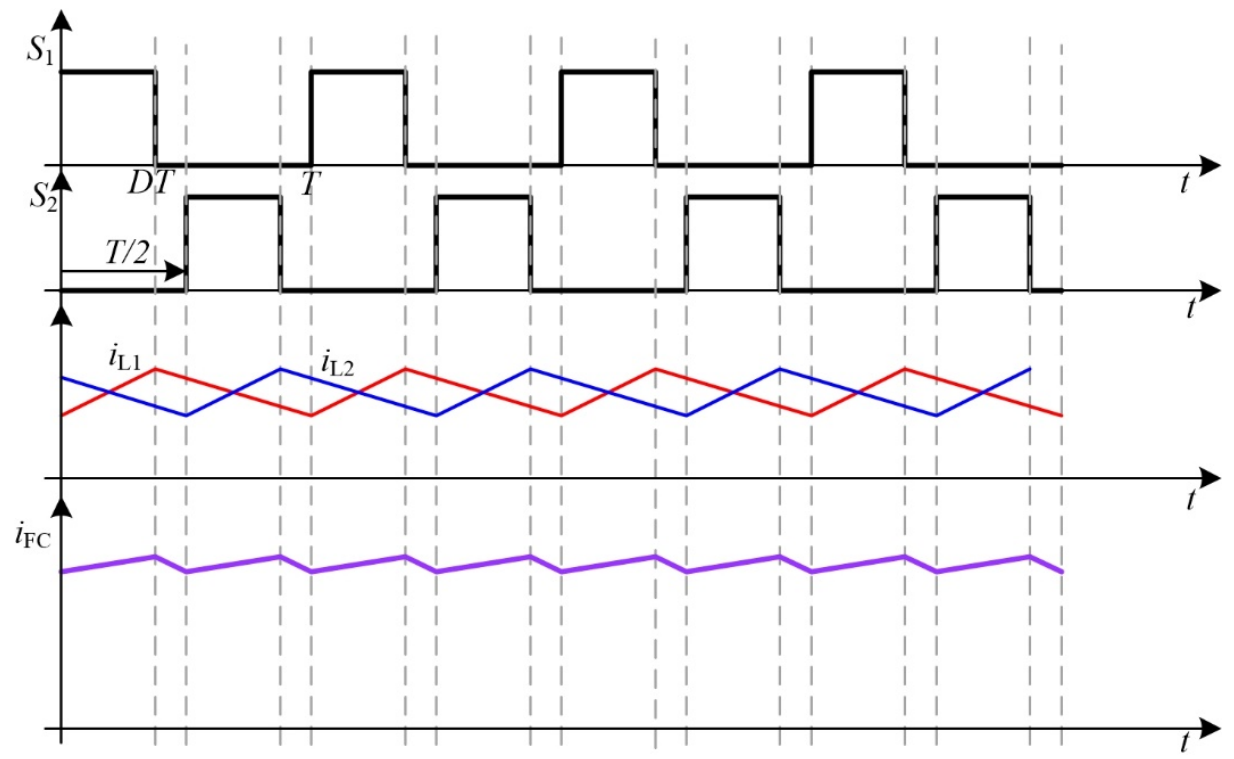

(b)

Figure 2. (a) Studied 2-phase parallel interleaved step-up converters as an FC converter (b) mode of operation.

As presented in [8], the dynamic behavior of CPLs is comparable to incremental negative impedance, which, under certain conditions, can introduce large oscillations or dangerous instability in the DC distribution. Stability issues should be considered to improve the performance of a DC bus. In recent years, there has been an effort to study and to solve instabilities introduced by CPL $[9,10]$. Various research has been conducted on this topic, using several control techniques. Glover and Sudhoff [11] initially proposed a nonlinear proportional-integral (PI) alleviating controller. The main drawback of this technique, as presented in [11], is its variable switching frequency. Subsequently, Emadi et al. [12] developed a sliding mode control for a buck converter under CPL; however, the key difficulty here is its sensitivity to excessive load variations. For other solutions, Cespedes et al. [13] studied passive damping techniques using a supplementary LC filter. Conversely, many active damping techniques have been studied to regulate the network: the "virtual inductor technique" proposed by Liu et al. [14]; the "virtual resistor approach" studied by You et al. [15]; and the "virtual impedance approach" proposed by Lu et al. [16]. Among these nonlinear control schemes, the interconnection and damping assignment passivity-based control (IDA-PBC, or the Hamiltonian Lyapunov control) has also received attention in the last decade to address the CPL instability issue $[17,18]$. This Hamiltonian energy control law is clear-cut, has high dynamics, and is sufficiently effective. 
This paper presents a novel Hamiltonian control approach for an FC converter. The key contributions of this study are as follows:

C1. To improve the system dynamics, the derivative term of the desired state vectors has been added to the new IDA-PBC law.

C2. Two integral terms have been added in the control law to confirm that there are no steady-state errors in the DC link voltage and to ensure current sharing in each input inductor current.

C3. The control interconnection gain ( $K_{\mathrm{J}}$ will be presented later) is the adaptive gain, updated every sampling period to find the optimum.

This study comprises five sections. After this introduction emphasizing the challenging issues with CPL and the current state of the field, Section 2 presents the Hamiltonian control law and Section 3 details the adaptive energy control approach for the multiphase FC boost power circuit. In Section 4, simulation and experimental results are presented to validate the adopted control approach. Finally, Section 5 concludes the study.

\section{Passivity Control Based on the Hamiltonian Control Law}

\subsection{System Modeling Based on the Port-Hamiltonian $p H$}

The nonlinear system has the general state-space model and can be expressed as:

$$
\dot{\mathrm{x}}=\mathrm{f}(\mathrm{x})+\mathrm{g} \cdot \mathrm{u}+\xi
$$

Then, Equation (1), expressed in the standard $\mathrm{pH}$ model (including storage components), can be presented as $[19,20]$ :

$$
\dot{\mathrm{x}}=[\mathrm{J}-\mathrm{R}] \frac{\partial H(\mathrm{x})}{\partial x}+\mathrm{g} \cdot \mathrm{u}+\xi
$$

where $\mathrm{u}$ is the important input control vector $\left(\in \Re^{\mathrm{m}}\right)$, $\mathrm{g}$ is the input matrix $(n \times m), \xi$ is the external disturbance vector, $x$ is the state variable vector $\left(\in \Re^{\mathrm{m}}\right), \mathrm{R}=\mathrm{R}^{\mathrm{T}} \geq 0$ is the damping matrix $(n \times n), \mathrm{J}=-\mathrm{J}^{\mathrm{T}}$ is the interconnection matrix $(n \times n)$, and $H(\mathrm{x})$ is the Hamiltonian stored energy function (a scalar field) of the controlled power plant.

\subsection{Proposed New Hamiltonian Control Law}

Referring to (2), the target is to determine the control input $\mathrm{u}=\beta(\mathrm{x})$ with $\mathrm{x}=\mathrm{x}_{\mathrm{d}}$ (the desired state variable), such that the feedback closed-loop model has the following proposed $\mathrm{pH}$ form (referred to as the "Hamiltonian energy control law" or the "IDA-PBC"):

$$
\dot{\mathrm{x}}=\left[\mathrm{J}_{\mathrm{d}}-\mathrm{R}_{\mathrm{d}}\right] \frac{\partial H_{\mathrm{d}}(\mathrm{x})}{\partial \mathrm{x}}+\frac{d \mathrm{x}_{\mathrm{d}}}{d t}
$$

where $\mathrm{J}_{\mathrm{d}}=-\mathrm{J}_{\mathrm{d}}{ }^{\mathrm{T}}$ is the control interconnection matrix, $\mathrm{R}_{\mathrm{d}}$ is the desired damping matrix, $\mathrm{R}_{\mathrm{d}}=\mathrm{R}_{\mathrm{d}}^{\mathrm{T}} \geq 0$, and $H_{\mathrm{d}}$ is the desired energy function. After assigning $J_{d}$ and $R_{d}$ matrices, the solutions of the partial differential equation (PDE) in (3) $\left[\partial H_{d} / \partial x\right]$ provide a valid set of the desired Hamiltonian energy functions $H_{\mathrm{d}}(\mathrm{x})$. Then, by combining (2) and (3), the most significant equation in the proposed new Hamiltonian control law can be written as:

$$
\overbrace{\left[\mathrm{J}_{\mathrm{d}}-\mathrm{R}_{\mathrm{d}}\right] \frac{\partial H_{\mathrm{d}}(\mathrm{x})}{\partial \mathrm{x}}+\frac{d \mathrm{x}_{\mathrm{d}}}{d t}}^{\text {Control Law }}=\overbrace{[\mathrm{J}-\mathrm{R}] \frac{\partial H(\mathrm{x})}{\partial \mathrm{x}}+\mathrm{g} \cdot \mathrm{u}+\xi}^{\text {Plant }}
$$

Finally, by solving Equation (4), the control input $\mathrm{u}=\beta(\mathrm{x})$ can be obtained.

\section{Adaptive Hamiltonian Energy Control of the FC Converter}

\subsection{2-Phase Interleaved Step-Up Power Circuit Model}

The topology of the two cell boost converters for FC applications is depicted in Figure $2 \mathrm{a} . S_{\mathrm{n}}$ is the power switch and $D_{\mathrm{n}}$ is the diode. $i_{\mathrm{FC}}$ is the FC current, $v_{\mathrm{FC}}$ is the FC 
voltage, and $p_{\mathrm{FC}}$ is the FC power $\left(=v_{\mathrm{FC}} \cdot i_{\mathrm{FC}}\right) . i_{\mathrm{CH}}$ is the load current, $v_{\mathrm{C}}$ is the DC bus voltage, $p_{\mathrm{CH}}$ is the load power $\left(=v_{\mathrm{FC}} \cdot i_{\mathrm{FC}}\right)$, and $i_{\mathrm{Ln}}$ is the inductor current. $C_{\mathrm{B}}$ is the total output capacitance at the DC bus and $L_{n}$ is the input inductance. In this work, two (2) phase converter cells are studied and implemented $(n=2)$. The two boost cells are formed by $\left\{S_{1}, D_{1}\right.$, and $\left.L_{1}\right\}$ and $\left\{S_{2}, D_{2}\right.$, and $\left.L_{2}\right\}$. The switching signals for triggering $S_{1}$ and $S_{2}$ are $180^{\circ}$ out of phase as displayed in Figure $2 \mathrm{~b}$. The input current $i_{\mathrm{FC}}$ is the sum of the two inductor currents $i_{\mathrm{L} 1}$ and $i_{\mathrm{L} 2}$. Since the inductor's ripple currents are out of phase, they cancel each other out and reduce the input ripple current caused by the boost inductors. The best input inductor ripple current cancellation occurs at $50 \%$ duty cycle.

The well-known nonlinear differential equation of multiphase boost converters [21,22] (average model) can be expressed as:

$$
\begin{gathered}
\frac{\mathrm{d} i_{\mathrm{L} 1}}{\mathrm{~d} t}=\left(v_{\mathrm{FC}}-r_{\mathrm{L} 1} i_{\mathrm{L} 1}-v_{\mathrm{C}}+d_{1} v_{\mathrm{C}}\right) / L_{1} \\
\frac{\mathrm{d} i_{\mathrm{L} 2}}{\mathrm{~d} t}=\left(v_{\mathrm{FC}}-r_{\mathrm{L} 2} i_{\mathrm{L} 2}-v_{\mathrm{C}}+d_{2} v_{\mathrm{C}}\right) / L_{2} \\
\frac{\mathrm{d} v_{\mathrm{C}}}{\mathrm{d} t}=\left(\left(1-d_{1}\right) i_{\mathrm{L} 1}+\left(1-d_{2}\right) i_{\mathrm{L} 2}-i_{\mathrm{CH}}\right) / C_{\mathrm{B}}
\end{gathered}
$$

where $d_{1}$ and $d_{2} \in[0,1]$ are the 1 st and 2 nd important control duty cycles ( $p u$.) of the power switches $\left(S_{1}\right.$ and $\left.S_{2}\right)$, which are control signals. $r_{\text {Ln }}$ is the equivalent series resistance $(E S R)$ of each inductor, $L_{n}$. Note here that $r_{L n}$ characterizes the fixed losses in each converter module. Moreover, for simplicity, the equivalent parallel resistance and the equivalent series resistance of the output capacitor $C_{B}$ are omitted in this study.

\subsection{Adaptive Hamiltonian Energy Control}

In this circuit, as shown in Figure 2, there are two important variables to be regulated:

1. The DC bus voltage $v_{\mathrm{C}}$ is the most essential variable so that, at the equilibrium point, $v_{\mathrm{C}}=v_{\mathrm{Cd}}$ (the desired set-point).

2. The current sharing of each input inductor current at equilibrium point $i_{\mathrm{L} 1}=i_{\mathrm{L} 2}$.

As highlighted in the literature concerning the control of fuel cell (FC) systems $[23,24]$, the cathode oxygen excess ratio (OER) has to be regulated to avoid oxygen starvation, decreased efficiency, degradations, and likely shutdown $[23,25]$. The oxygen starvation phenomenon appears when the quantity of oxygen provided to the FC is not adequate to react with the stack current [23]. Hence, different control strategies have been conceived to face this crucial issue, such as the control of stack current derivative [24,26]. As this paper is mainly focused on CPL issues and not OER issues, only two variables have been taken into account, including the DC bus voltage for stability reasons, and the current of each inductor phase of the converter to avoid additional current stresses (causing a decrease in energy efficiency and possible power switch failures). Nevertheless, OER issues are considered and discussed when presenting the obtained experimental results in Section 4.

To guarantee robustness against the converter parameter variations (e.g., the resistor $r_{\text {Ln }}$ variations with temperature), noise, or external perturbations, the implementation of integral terms are mandatory. For the first constraints above $v_{\mathrm{C}}=v_{\mathrm{Cd}}$, the new control law $\lambda_{\mathrm{V}}$ has the integral form:

$$
\lambda_{\mathrm{V}}=K_{\mathrm{IV}} \int\left(v_{\mathrm{Cd}}-v_{\mathrm{C}}\right) d t
$$

where $K_{\mathrm{IV}} \geq 0$ is the tuning integral gain for the voltage regulation. Next, for the second constraints $i_{\mathrm{L} 1}=i_{\mathrm{L} 2}$, the new control law, $\lambda_{\mathrm{I}}$, has the integral form:

$$
\lambda_{\mathrm{I}}=K_{\mathrm{II}} \int\left(i_{\mathrm{L} 2}-i_{\mathrm{L} 1}\right) d t
$$

where $K_{\mathrm{II}} \geq 0$ is the tuning integral gain for the current sharing. 
According to (5)-(7), the modified FC converter model with two additional Integrators (8) and (9) can be written in $\mathrm{pH}$ form (2), as follows:

$$
\mathbf{x}=\left[\begin{array}{l}
x_{1} \\
x_{2} \\
x_{3} \\
x_{4} \\
x_{5}
\end{array}\right]=\left[\begin{array}{l}
i_{\mathrm{L} 1} \\
i_{\mathrm{L} 2} \\
v_{\mathrm{C}} \\
\lambda_{\mathrm{V}} \\
\lambda_{\mathrm{I}}
\end{array}\right], u=\left[\begin{array}{l}
u_{1} \\
u_{2}
\end{array}\right]=\left[\begin{array}{l}
d_{1} \\
d_{2}
\end{array}\right] .
$$

Subsequently, the extended Hamiltonian function in the proposed quadratic equation $[27,28]$ is set as:

$$
\begin{gathered}
H(\mathbf{x})=\frac{1}{2} \mathrm{x}^{\mathrm{T}} \mathrm{Q} x, \\
\text { where } \mathrm{Q}=\operatorname{diag}\left\{L_{1}, L_{2}, C_{\mathrm{B}}, 1 / K_{\mathrm{IV}}, 1\right\},
\end{gathered}
$$

which can therefore be written as:

$$
H(\mathrm{x})=\frac{1}{2}\left(L_{1} x_{1}^{2}+L_{2} x_{2}^{2}+C_{\mathrm{B}} x_{3}^{2}+K_{\mathrm{IV}}{ }^{-1} x_{4}^{2}+x_{5}^{2}\right)
$$

Therefore, the gradient of a scalar field $H(\mathrm{x})$ may be expressed as:

$$
\frac{\partial H(\mathrm{x})}{\partial \mathrm{x}}=\left[\begin{array}{lllll}
L_{1} x_{1} & L_{2} x_{2} & C_{\mathrm{B}} x_{3} & K_{\mathrm{IV}}{ }^{-1} x_{4} & x_{5}
\end{array}\right]^{\mathrm{T}}
$$

Then, the matrices $\mathrm{J}-\mathrm{R}$ and $\mathrm{g}$ and vector $\xi$ can be expressed as:

$$
\begin{gathered}
\mathrm{J}-\mathrm{R}=\left[\begin{array}{ccccc}
-r_{\mathrm{L} 1} / L_{1}^{2} & 0 & -1 /\left(L_{1} C_{\mathrm{B}}\right) & 0 & 0 \\
0 & -r_{\mathrm{L} 2} / L_{2}^{2} & -1 /\left(L_{2} C_{\mathrm{B}}\right) & 0 & 0 \\
1 /\left(L_{1} C_{\mathrm{B}}\right) & 1 /\left(L_{2} C_{\mathrm{B}}\right) & 0 & 0 & 0 \\
0 & 0 & -K_{\mathrm{IV}} / C_{\mathrm{B}} & 0 & 0 \\
-K_{\mathrm{II}} / L_{1} & K_{\mathrm{II}} / L_{2} & 0 & 0 & 0
\end{array}\right] \\
\mathrm{g}=\left[\begin{array}{cc}
x_{3} / L_{1} & 0 \\
0 & x_{3} / L_{2} \\
-x_{1} / C_{\mathrm{B}} & -x_{2} / C_{\mathrm{B}} \\
0 & 0 \\
0 & 0
\end{array}\right] \text {, and } \xi=\left[\begin{array}{c}
v_{\mathrm{FC}} / L_{1} \\
v_{\mathrm{FC}} / L_{2} \\
-i_{\mathrm{CH}} / C_{\mathrm{B}} \\
K_{\mathrm{IV}} v_{\mathrm{Cd}} \\
0
\end{array}\right] .
\end{gathered}
$$

Next, to apply the Hamiltonian energy control law defined in (3), it is essential to state the desired set-point vector $\mathrm{x}_{\mathrm{d}}=\left[x_{1 \mathrm{~d}}, x_{2 \mathrm{~d}}, x_{3 \mathrm{~d}}, x_{4 \mathrm{~d}}, x_{5 \mathrm{~d}}\right]^{\mathrm{T}}$ (also identified as the steady-state vector) and the error vector $\mathrm{e}=\left[e_{1}, e_{2}, e_{3}, e_{4}, e_{5}\right]^{\mathrm{T}}$. One may write:

$$
\mathrm{e}=\mathrm{x}_{\mathrm{d}}-\mathrm{x}
$$

Subsequently, according to (11)-(13), $H_{\mathrm{d}}$ [refer to (3)] was chosen as the proposed quadratic function:

$$
\begin{aligned}
& H_{\mathrm{d}}(\mathrm{x})=\frac{1}{2} \mathrm{e}^{\mathrm{T}} \mathrm{Q} \mathrm{e} \\
& H_{\mathrm{d}}(\mathrm{x})=\frac{1}{2} L_{1} \cdot\left(x_{1 \mathrm{~d}}-x_{1}\right)^{2}+\frac{1}{2} L_{2} \cdot\left(x_{2 \mathrm{~d}}-x_{2}\right)^{2}+\frac{1}{2} C_{\mathrm{Bus}} \cdot\left(x_{3 \mathrm{~d}}-x_{3}\right)^{2}+\frac{1}{2} K_{\mathrm{IV}}^{-1} \cdot x_{4}^{2}+\frac{1}{2} \cdot x_{5}^{2} \\
& \frac{\partial H_{\mathrm{d}}(\mathrm{x})}{\partial \mathrm{x}}=\left[\begin{array}{lllll}
L\left(x_{1}-x_{1 \mathrm{~d}}\right) & L\left(x_{2}-x_{2 \mathrm{~d}}\right) & C_{\mathrm{B}}\left(x_{3}-x_{3 \mathrm{~d}}\right) & K_{\mathrm{IV}}{ }^{-1} x_{4} & x_{5}
\end{array}\right]^{\mathrm{T}}
\end{aligned}
$$


In terms of the energy shaping and damping control [29,30], the control interconnection matrix $\mathrm{J}_{\mathrm{d}}$ and control damping matrix $\mathrm{R}_{\mathrm{d}}$ are proposed as follows:

$$
\begin{gathered}
\mathrm{J}_{\mathrm{d}}=\left[\begin{array}{ccccc}
0 & 0 & -\frac{1+K_{\mathrm{I}}}{L C_{\mathrm{B}}} & 0 & \frac{K_{\mathrm{II}}}{L} \\
0 & 0 & -\frac{1+K_{\mathrm{J}}}{L C_{\mathrm{B}}} & 0 & -\frac{K_{\mathrm{II}}}{L} \\
1+K_{\mathrm{I}} & \frac{1+K_{\mathrm{I}}}{L C_{\mathrm{B}}} & 0 & \frac{K_{\mathrm{IV}}}{C_{\mathrm{B}}} & 0 \\
\frac{L C_{\mathrm{B}}}{L} & 0 & -\frac{K_{\mathrm{IV}}}{C_{\mathrm{B}}} & 0 & 0 \\
-\frac{K_{\mathrm{II}}}{L} & \frac{K_{\mathrm{II}}}{L} & 0 & 0 & 0
\end{array}\right] \\
\mathrm{R}_{\mathrm{d}}=\left[\begin{array}{ccccc}
\frac{K_{\mathrm{R}}}{L^{2}} & 0 & 0 & 0 & 0 \\
0 & \frac{K_{\mathrm{R}}}{L^{2}} & 0 & 0 & 0 \\
0 & 0 & 0 & 0 & 0 \\
0 & 0 & 0 & 0 & 0 \\
0 & 0 & 0 & 0 & 0
\end{array}\right]
\end{gathered}
$$

where $\mathrm{J}_{\mathrm{d}}=-\mathrm{J}_{\mathrm{d}}{ }^{\mathrm{T}}, \mathrm{R}_{\mathrm{d}}=\mathrm{R}_{\mathrm{d}}{ }^{\mathrm{T}} \geq 0$, and $K_{\mathrm{R}} \in \Re \geq 0$ is the tuning controller used to dampen the transient oscillations. $K_{\mathrm{J}} \in \Re$ is the real-time adaptive gain.

Substituting (10), (14)-(16), and (20)-(22) into (4), results in five equations, after some algebra. As a final point, one solves (4); therefore, the last two bottom equations are equal to zero, with $x_{1 \mathrm{~d}}=x_{2 \mathrm{~d}}$ (which will be presented later). There are three (3) equations and three (3) unknown signals $\left(u_{1}\left(=d_{1}\right), u_{2}\left(=d_{2}\right)\right.$, and $\left.K_{\mathrm{J}}\right)$ to be estimated with three fixed tuning controller gains: $K_{\mathrm{R}}, K_{\mathrm{IV}}$, and $K_{\mathrm{II}}$. By using the MATLAB code of the solve() function, the unique result of the proposed adaptive Hamiltonian control law can be written as:

$$
\begin{gathered}
K_{\mathrm{J}}=-\left(i_{\mathrm{CH}} \cdot x_{3}-v_{\mathrm{FC}} \cdot x_{1}-v_{\mathrm{FC}} \cdot x_{2}+x_{3} \cdot x_{4}+x_{1} \cdot x_{3 \mathrm{~d}}-x_{3} \cdot x_{1 \mathrm{~d}}+x_{2} \cdot x_{3 \mathrm{~d}}-x_{3} \cdot x_{2 \mathrm{~d}}-K_{\mathrm{R}} \cdot x_{1}{ }^{2}-K_{\mathrm{R}} \cdot x_{2}{ }^{2}+\ldots\right. \\
r \mathrm{~L} \cdot x_{1}{ }^{2}+r \mathrm{~L} \cdot x_{2}{ }^{2}+C_{\mathrm{B}} \cdot x_{3} \cdot\left(\mathrm{d} x_{3 \mathrm{~d}} / \mathrm{d} t\right)+L \cdot x 1 \cdot\left(\mathrm{d} x_{1 \mathrm{~d}} / \mathrm{d} t\right)+L \cdot x_{2} \cdot\left(\mathrm{d} x_{2 \mathrm{~d}} / \mathrm{d} t\right)+K_{\mathrm{II}} \cdot x_{1} \cdot x_{5}-K_{\mathrm{II}} \cdot x_{2} \cdot x_{5}+\ldots \\
\left.K_{\mathrm{R}} \cdot x_{1} \cdot x_{1 \mathrm{~d}}+K_{\mathrm{R}} \cdot x_{2} \cdot x_{2 \mathrm{~d}}\right) /\left(x_{1} \cdot x_{3 \mathrm{~d}}-x_{3} \cdot x_{1 \mathrm{~d}}+x_{2} \cdot x_{3 \mathrm{~d}}-x_{3} \cdot x_{2 \mathrm{~d}}\right) . \\
d_{1}=u_{1}=\left(x_{3 \mathrm{~d}}-v_{\mathrm{FC}}+r_{\mathrm{L}} \cdot x_{1}+K_{\mathrm{R}} \cdot\left(x_{1 \mathrm{~d}}-x_{1}\right)+K_{\mathrm{J}} \cdot\left(x_{3 \mathrm{~d}}-x_{3}\right)+K_{\mathrm{II}} \cdot x_{5}+L \cdot\left(\mathrm{d} x_{1 \mathrm{~d}} / \mathrm{d} t\right)\right) / x_{3} . \\
d_{2}=u_{2}=\left(x_{3 \mathrm{~d}}-v_{\mathrm{FC}}+r_{\mathrm{L}} \cdot x_{2}+K_{\mathrm{R}} \cdot\left(x_{2 \mathrm{~d}}-x_{2}\right)+K_{\mathrm{J}} \cdot\left(x_{3 \mathrm{~d}}-x_{3}\right)-K_{\mathrm{II}} \cdot x_{5}+L \cdot\left(\mathrm{d} x_{2 \mathrm{~d}} / \mathrm{d} t\right)\right) / x_{3} .
\end{gathered}
$$

\subsection{Desired Set-Point Generation $x_{d}$}

According to (20) and (23)-(25), the state variables $x_{1}\left(=i_{\mathrm{L} 1}\right), x_{2}\left(=i_{\mathrm{L} 2}\right)$, and $x_{3}\left(=v_{\mathrm{C}}\right)$ are measurable via current and voltage sensors; the state variables $x_{4}$ and $x_{5}$ are calculated using (8) and (9); and, finally, the three desired variables $\left(x_{1 \mathrm{~d}}\left(=i_{\mathrm{L} 1 \mathrm{~d}}\right), x_{2 \mathrm{~d}}\left(=i_{\mathrm{L} 2 \mathrm{~d}}\right)\right.$, and $\left.x_{3 \mathrm{~d}}\left(=v_{\mathrm{Cd}}\right)\right)$ need to be determined. According to its application, the utility DC link voltage $v_{\mathrm{C}}$ of a DC microgrid is set as $v_{\mathrm{Cd}}=270 \mathrm{~V}$ for electric aircraft, or 300-540 V for electric/hybrid/fuel cell vehicles. To estimate $\left[x_{1 \mathrm{~d}}\left(=i_{\mathrm{L} 1 \mathrm{~d}}\right), x_{2 \mathrm{~d}}\left(=i_{\mathrm{L} 2 \mathrm{~d}}\right)\right]$, first, the load power $p_{\mathrm{CH}}$ can be expressed as:

$$
p_{\mathrm{CH}}=v_{\mathrm{C}} \cdot i_{\mathrm{CH}}=x_{3} \cdot i_{\mathrm{CH}} .
$$

According to (8), the load power $p_{\mathrm{CH}}$ can be simplified as:

$$
p_{\mathrm{CH}}=x_{3 \mathrm{~d}} \cdot i_{\mathrm{CH}}+x_{3 \mathrm{~d}} \cdot x_{4} .
$$

According to the power balance at the equilibrium point of (5)-(7) ( $\mathrm{dx} / \mathrm{d} t=0$ and $\mathrm{x}=\mathrm{x}_{\mathrm{d}}$ ), the FC power set-point $p_{\mathrm{FCd}}$ may be written as:

$$
p_{\mathrm{FCd}}=2 p_{\mathrm{Max}}\left(1-\sqrt{1-\left(\frac{p_{\mathrm{CH}}}{p_{\mathrm{Max}}}\right)}\right) \text {, with } p_{\mathrm{Max}}=\frac{v_{\mathrm{FC}}^{2}}{2 r_{\mathrm{L}}} .
$$


Then, $x_{1 \mathrm{~d}}\left(=i_{\mathrm{L} 1 \mathrm{~d}}\right)$ and $x_{2 \mathrm{~d}}\left(=i_{\mathrm{L} 2 \mathrm{~d}}\right)$ can be expressed as:

$$
x_{1 \mathrm{~d}}=x_{2 \mathrm{~d}}=\left(\frac{p_{\mathrm{FCd}}}{v_{\mathrm{FC}}}\right) / 2
$$

Now, the explanations to establish $\mathrm{x}_{\mathrm{d}}$ are completed.

\subsection{Stability Proof and Control Conclusion}

The Lyapunov stability theory is employed to verify the stability of the proposed control law (23)-(25). $\quad H_{\mathrm{d}}(\mathrm{x})$ (see (18) and (19)) is a positive-definite function and $\mathrm{e}=\mathrm{x}_{\mathrm{d}}-\mathrm{x}$; then, $H_{\mathrm{d}}(\mathrm{e})$ may be written. Consequently, $H_{\mathrm{d}}(\mathrm{e})$ can be set as the Lyapunov candidate function $V$ [30], which can be written as:

$$
V(\mathrm{e})=H_{\mathrm{d}}(\mathrm{e})>0 .
$$

According to (20), the gradient of a scalar field $H_{\mathrm{d}}(\mathrm{x})$ can be extended as follows:

$$
\frac{\partial H_{\mathrm{d}}(\mathrm{x})}{\partial \mathrm{x}}=-\mathrm{Qe}
$$

Next, the derivative of the error e can be expressed as:

$$
\dot{\mathrm{e}}=\dot{\mathrm{x}}_{\mathrm{d}}-\dot{\mathrm{x}}
$$

Substituting (3) and (31) into (32), we obtain:

$$
\dot{\mathrm{e}}=\left[\mathrm{J}_{\mathrm{d}}-\mathrm{R}_{\mathrm{d}}\right][-\mathrm{Qe}] .
$$

As a result, the derivative of $V(\mathrm{e})$ can be presented as

$$
\dot{V}(\mathrm{e})=\frac{\partial H_{\mathrm{d}}(\mathrm{e})}{\partial \mathrm{e}} \dot{\mathrm{e}}=[-\mathrm{Qe}]^{\mathrm{T}}\left[\mathrm{J}_{\mathrm{d}}-\mathrm{R}_{\mathrm{d}}\right][-\mathrm{Qe}]
$$

$\mathrm{J}_{\mathrm{d}}$ is an anti-symmetric matrix $\left(\mathrm{J}_{\mathrm{d}}=-\mathrm{J}_{\mathrm{d}}{ }^{\mathrm{T}}\right)$, then $[-\mathrm{Qe}]^{\mathrm{T}} \mathrm{J}_{\mathrm{d}}[-\mathrm{Qe}] \equiv 0$ and $\mathrm{R}_{\mathrm{d}}$ is a positivedefinite matrix $\left(\mathrm{R}_{\mathrm{d}}=\mathrm{R}_{\mathrm{d}}^{\mathrm{T}} \geq 0\right)$. Therefore, the derivative of $V(\mathrm{e})$ can be expressed as:

$$
\dot{V}(\mathrm{e})=-[-\mathrm{Qe}]^{\mathrm{T}} \mathrm{R}_{\mathrm{d}}[-\mathrm{Qe}]<0 .
$$

Combining the results $V(\mathrm{e})>0$ and $\dot{V}(\mathrm{e})<0$, the proposed control law exhibits asymptotical stability at the operating fixed point $[31,32]$, thus completing the proof starting at the beginning of Section 3.4.

For tuning the controller gains linked to the stability margin, only three tuned controller parameters are available: $K_{\mathrm{R}}, K_{\mathrm{IV}}$, and $K_{\mathrm{II}}$. The damping controller $K_{\mathrm{R}}$ is homogeneous to the resistor; it is set at no more than 5-10 times the value of the inductive resistance $r_{\mathrm{L}}$. This restriction allows ensuring an underdamped transient behavior with low overshoot and a fast response. The damping controller $K_{R}$ has been set to 0.5 to obtain a faster response as a result of the operating condition changes. Finally, according to the Nyquist-Shannon theorem and (24) and (25), the relationship between the integrator's time constants $\left(\left(=1 / K_{\mathrm{IV}}\right)\right.$, and $\left.\left(=1 / K_{\mathrm{II}}\right)\right)$ and the well-known boost converter natural frequency $\omega_{\mathrm{n}}\left[=1 / \operatorname{sgrt}\left(L \cdot C_{\mathrm{B}}\right)\right.$ is roughly expressed using the cascade control loop: $K_{\mathrm{II}}<<K_{\mathrm{IV}}<<\omega_{\mathrm{n}}$. The natural frequency of the converter is equal to $503.6 \mathrm{~Hz}$, while the period is equal to $1.98 \mathrm{~ms}$. Based on the Nyquist-Shannon theorem, the sampling period has to be equal at least to $4 \mathrm{~ms}$ (double the period). As a result, the integrator's time constants in the current sharing regulation is set to $8 \mathrm{~ms}$; while for the DC bus voltage regulation, the time constant is set six times higher, equal to $50 \mathrm{~ms}$. Thus, the tuning integral gains $K_{\mathrm{IV}}$ and $K_{\mathrm{II}}$ are set to 120 and 20, respectively. 
The control approach of the interleaved FC step-up converter is shown in Figure 3. Integrator (8) generates $x_{4}$, Integrator (9) calculates $x_{5}$, and the desired set-point generator (26)-(29) estimates the desired inductor currents $i_{\mathrm{Ld}}\left(=x_{1 \mathrm{~d}}=x_{2 \mathrm{~d}}\right)$. Next, Equation (23) generates the adaptive gain $K_{\mathrm{J}}$, resulting in the real-time estimated gain, updated every sampling period. Finally, the control vector generation in (24) and (25) introduces the duty cycles $\mathrm{u}\left(u_{1}, u_{2}\right)$.

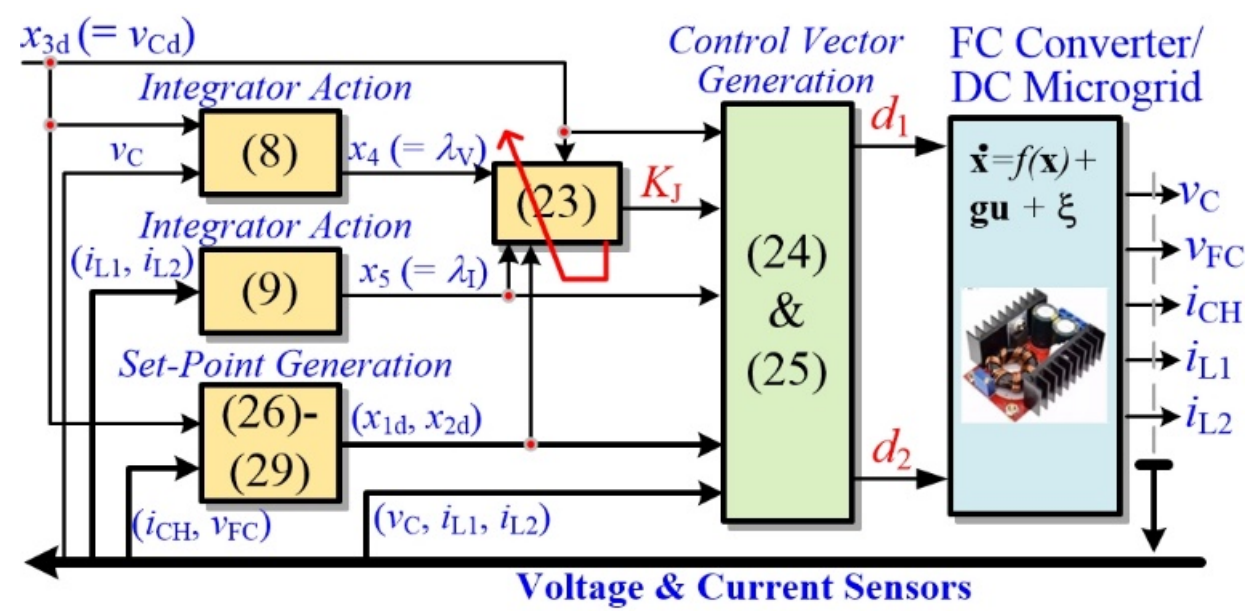

Figure 3. Adaptive Hamiltonian control for the FC step-up converter.

\section{Performance Validation}

Figure 4 illustrates the test bench platform, which comprises a real PEMFC/Reformer (ME2 ${ }^{2}$ Power ${ }^{\mathrm{TM}}$ FC system: $2.5 \mathrm{~kW}, 50 \mathrm{~V}$ ), 2-phase FC step-up converter, and loads, using the parameters in Table 1 . By choosing a phase inductor value equal to $200 \mu \mathrm{H}$, the FC current ripple is restricted between 0.8 and $2.5 \mathrm{~A}$, allowing a guarantee of the FC reliability [4]. In comparison, the inductor current ripple varies from 4.86 to $5.5 \mathrm{~A}$. Regarding the DC bus voltage ripple, it is limited to $0.5 \mathrm{~V}$ by using a DC bus capacitor equal to $500 \mu \mathrm{F}$. The electronic load Chroma ${ }^{\mathrm{TM}}$ 63212E-600-840 was used to emulate the CRL and CPL. All control algorithms were digitally estimated in MicroLabBox dSPACE DS1103 (sampling frequency $=25 \mathrm{kHz}$, i.e., a high switching frequency $f_{\mathrm{s}}$ of $25 \mathrm{kHz}$ of the boost power circuits) with the controller parameters listed in Table 2. It should be noted here that it is beyond the scope of this paper to discuss the sampling time delay (for example, single update or double update); more details can be found in $[33,34]$.

Table 1. Two-phase fuel cell boost circuit parameters.

\begin{tabular}{ccc}
\hline Symbol & Parameter & Value \\
\hline$v_{\mathrm{FC}}$ & Nominal input FC voltage & $50 \mathrm{~V}$ \\
$v_{\mathrm{C}}$ & DC bus voltage & $110 \mathrm{~V}$ \\
$L=L_{1}=L_{2}$ & Inductance & $200 \mu \mathrm{H}$ \\
$r_{\mathrm{L}}=r_{\mathrm{L} 1}=r_{\mathrm{L} 2}$ & Resistance $E S R s$ & $0.1 \Omega$ \\
$C_{\mathrm{B}}$ & Total dc bus capacitance & $500 \mu \mathrm{F}$ \\
$S_{1}=S_{2}$ & MOSFET (IXFN90N85X) & $850 \mathrm{~V}, 90 \mathrm{~A}$ \\
$f_{\mathrm{S}}$ & Switching frequency & $25 \mathrm{kHz}$ \\
\hline
\end{tabular}


2-Phase Interleaved Boost Converter

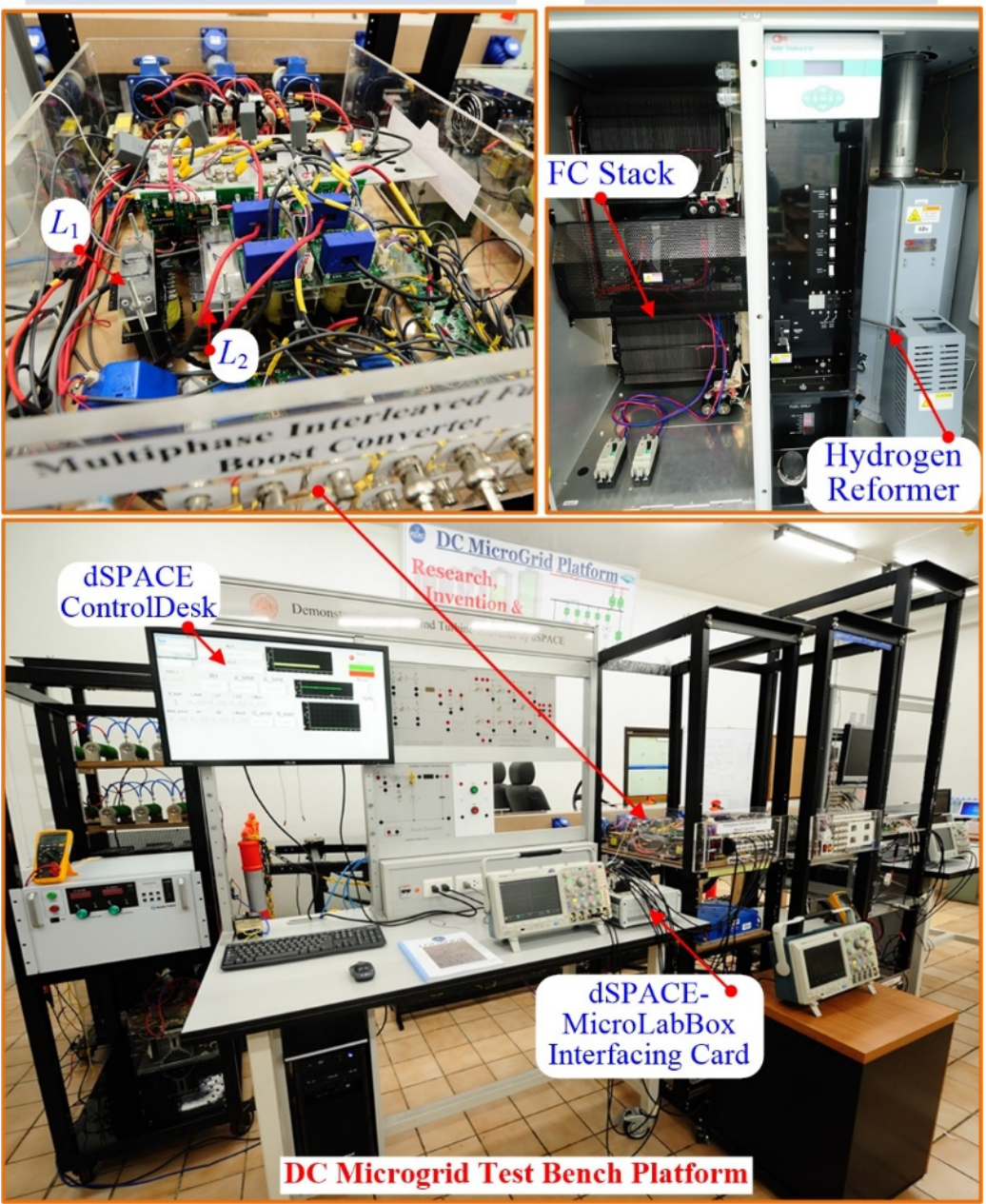

Figure 4. Laboratory test-bench of the DC microgrid platform.

Table 2. Control System Parameters.

\begin{tabular}{cc}
\hline Symbol & Value/Unit \\
\hline$v_{\mathrm{Cd}}$ & $110 \mathrm{~V}$ \\
$K_{\mathrm{R}}$ & 0.5 \\
$K_{\mathrm{IV}}$ & 120 \\
$K_{\mathrm{II}}$ & 20 \\
\hline
\end{tabular}

First, to validate the current-sharing $i_{\mathrm{L} 1}=i_{\mathrm{L} 2}$ and the input-current ripple cancellation of the interleaving switching technique, the equilibrium-point data in Figure 5 illustrates the characteristics of the power converters at $v_{\mathrm{Cd}}=v_{\mathrm{C}}=110 \mathrm{~V}$ and $p_{\mathrm{CH}} \approx p_{\mathrm{FC}}=352 \mathrm{~W}$ (CPL). CH1-CH6 denote the DC bus voltage $v_{\mathrm{C}}$, fuel cell voltage $v_{\mathrm{FC}}$, fuel cell current $i_{\mathrm{FC}}$, first inductor current $i_{\mathrm{L} 1}$, second inductor current $i_{\mathrm{L} 2}$, and integral output variable $x_{5}$ $\left(=\lambda_{\mathrm{I}}\right.$, see (9)), respectively. As a result of the integral action (9) with a small signal $x_{5}$ of approximately 0.03 The two-phase boost circuits use controlled current balancing $i_{\mathrm{L} 1}=i_{\mathrm{L} 2}$ (average currents). Each circuit operates $180^{\circ}$ out of phase at $f_{\mathrm{s}}=25 \mathrm{kHz}$. Therefore, the peak-to-peak ripple current $i_{\mathrm{FC}}$ switches at an effective frequency $(50 \mathrm{kHz})$ of twice the PWM frequency $f_{\mathrm{S}}$ as $i_{\mathrm{FC}}=i_{\mathrm{L} 1}+i_{\mathrm{L} 2}$. 


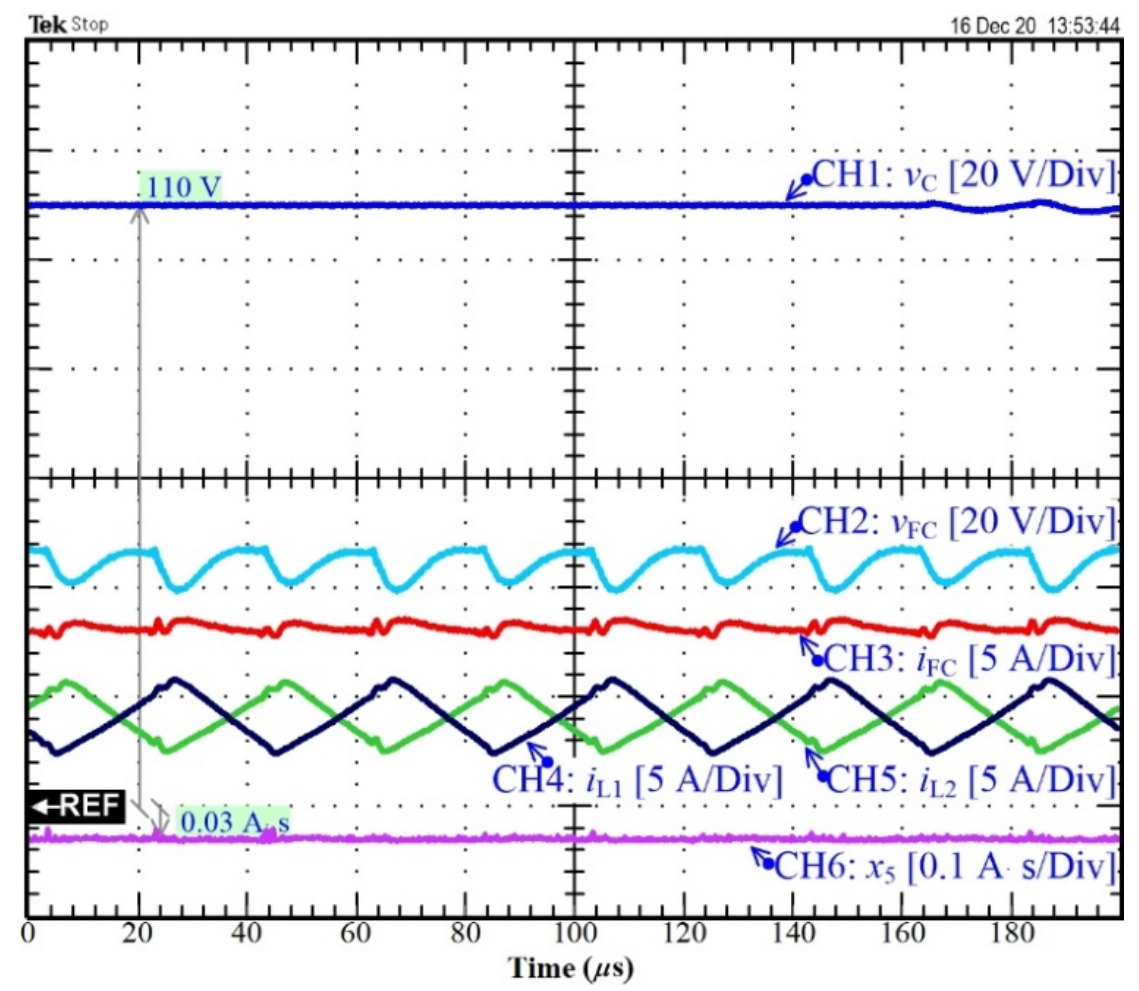

Figure 5. Experimental results: equilibrium-point waveforms of the $\mathrm{FC}$ converter at $v_{\mathrm{Cd}}=v_{\mathrm{C}}=110 \mathrm{~V}$ and $p_{\mathrm{CH}} \approx 352 \mathrm{~W}$.

Next, to substantiate the effectiveness of the studied adaptive energy control approach for the DC microgrid during the CPL step, a simulation analysis is also performed on the MATLAB/SIMULINK program by using the switching model. Figure 6 displays the simulation and experimental results obtained for the converter regulator with the proposed control law. CH1-CH11 show the DC bus voltage $v_{\mathrm{C}}, \mathrm{FC}$ voltage $v_{\mathrm{FC}}, \mathrm{FC}$ power $p_{\mathrm{FC}}$, external load power $p_{\mathrm{CH}}$, 1st input inductor current $i_{\mathrm{L} 1}$, 2nd input inductor current $i_{\mathrm{L} 2}$, 1 st control duty cycle $d_{1}$, 2nd control duty cycle $d_{2}$, input FC current $i_{\mathrm{FC}}$, integral output variable $x_{4}\left[=\lambda_{\mathrm{V}}\right.$, see (8)], and adaptive gain $K_{\mathrm{J}}$, respectively. The CPL changes immediately from 245 to $980 \mathrm{~W}$ due to the applied power load step. For this dynamic test, the voltage gain of the converter varies from 2.2, to 3 since the FC stack voltage is included between 36 and $50 \mathrm{~V}$, guaranteeing a good energy efficiency. In comparison, the duty cycle values vary from 0.54 to 0.67 . The DC bus voltage undershoots when the power increases $7.27 \%$ $(8 \mathrm{~V})$, and the associated settling time is $10 \mathrm{~ms}$ (see Table 3 ). The adaptive gain $K_{\mathrm{J}}$ is updated to find an optimum value, depending on the equilibrium point. For example, in Figure $6 \mathrm{~b}, K_{\mathrm{J}}=0.53\left(\right.$ at $\left.p_{\mathrm{CH}}=245 \mathrm{~W}\right)$ and $K_{\mathrm{J}}=-0.60\left(\right.$ at $\left.p_{\mathrm{CH}}=980 \mathrm{~W}\right)$. It should be noted that the steady-state error is $e_{3}=0\left(v_{\mathrm{Cd}}=v_{\mathrm{C}}=110 \mathrm{~V}\right)$ because the integral term $(8)$ is realized in the control law. As a result of a CPL step, the stack current shows a slight overshoot (32 A, corresponding to $12.5 \%$ of the steady-state current of $28 \mathrm{~A}$ ) reached in $3 \mathrm{~ms}$. On one hand, if the studied converter was supplied by a Ballard $1.2 \mathrm{~kW}$ Nexa FC (generally used in the literature for control purposes) $[23,24]$, this test with a large CPL step (around $635 \mathrm{~W}$ ) would have likely led up to oxygen starvation and a shutdown, since the proposed control does not include the regulation of the stack current derivative. On the other hand, in the current work, the ME2PowerTM FC system supplied by a methanol-reformer feeds a two-phase interleaved boost converter. Compared to the Ballard $1.2 \mathrm{~kW}$ Nexa FC, this FC system can be supplied with an adequate hydrogen quantity to consequently avoid any shutdown risk in the case of a sudden CPL change. However, the FC stack voltage continues to drop despite the FC stack current having reached a steady-state operation (10 ms after applying the CPL step). Due to the decrease in the FC stack voltage (around $4 \mathrm{~V}$ for $50 \mathrm{~ms}$ ) and the FC power, a possible oxygen starvation phenomenon occurred [23]. 
It may lead to energy efficiency loss and long-term degradation. In summary, mitigation strategies are needed to optimize the performance and the reliability of the FC [24].
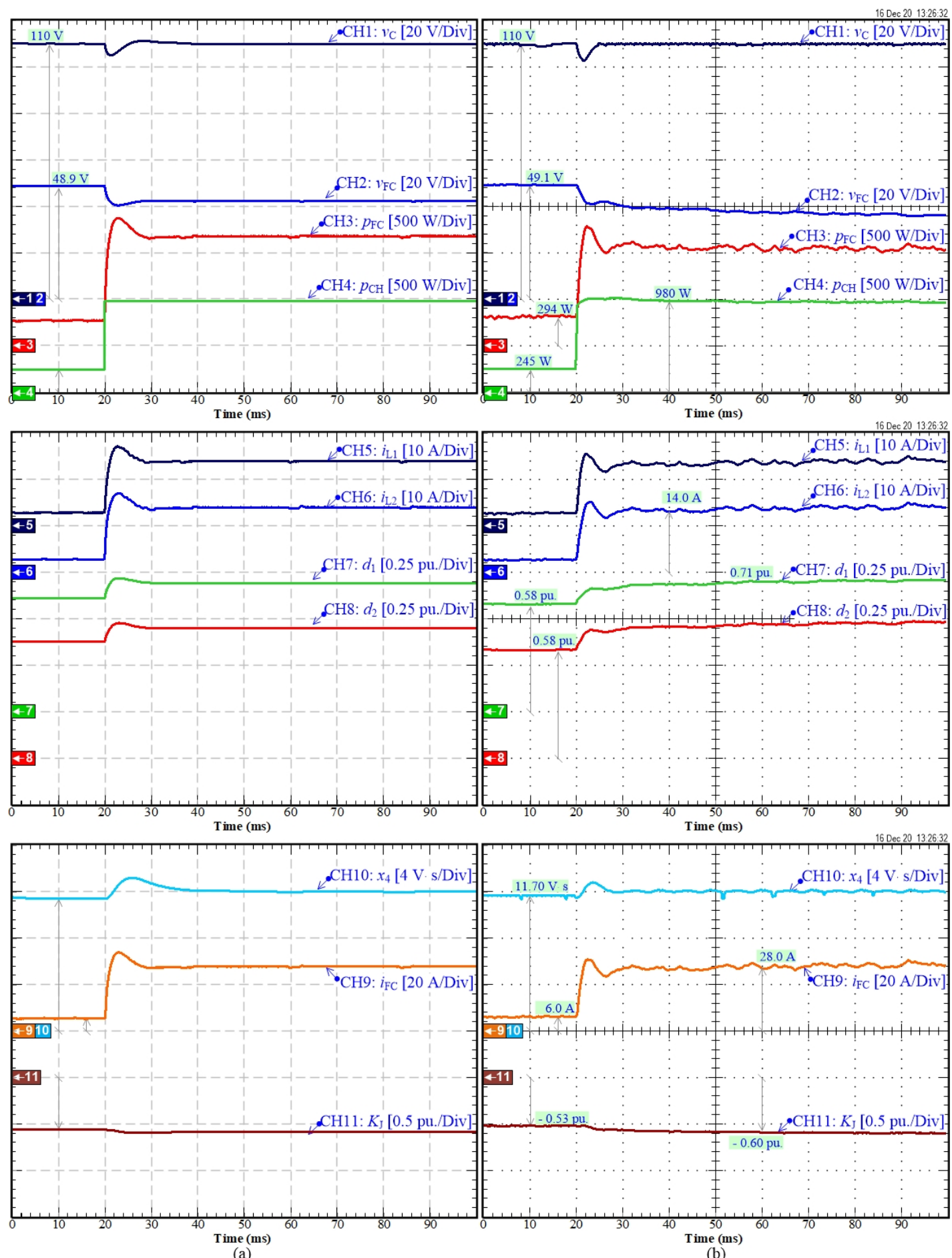

Figure 6. Dynamic characteristic of the power circuit in a CPL step from $245 \mathrm{~W}$ to $980 \mathrm{~W}$ : (a) simulation results and (b) experimental results. 
Table 3. Settling time and undershoot voltage $v_{\mathrm{C}}$ under CPL step from $245 \mathrm{~W}$ to $980 \mathrm{~W}$.

\begin{tabular}{ccc}
\hline & Simulation Results & Experimental Result \\
\hline Settling time $t_{\mathrm{st}}$ & $\approx 10 \mathrm{~ms}$ & $\approx 10 \mathrm{~ms}$ \\
\hline Undershoot voltage $v_{\mathrm{C}}$ & $6 \mathrm{~V}$ & $8 \mathrm{~V}$ \\
\hline
\end{tabular}

Finally, for the experimental results in Figure $6 \mathrm{~b}$ after the CPL step (after $\mathrm{t}=20 \mathrm{~ms}$ ), there are some noises in measured waveforms (at high current and high electromagnetic interference EMI) because the laboratory test bench is in an environment of strong EMI (caused by the power electronics' switching frequency). A significant agreement can be observed between the simulation and the experimental results in the laboratory test bench, indicating that the network modeling was accurate.

To clarify the advantages of the proposed Hamiltonian control law, a comparison is made between the proposed control law and the traditional cascaded linear proportionalintegral (PI) control method [35,36]. First, the conventional outer-loop PI voltage controller is written as:

$$
\begin{gathered}
p_{\mathrm{FCd}}=K_{\mathrm{Pv}}\left(v_{\mathrm{Cd}}-v_{\mathrm{C}}\right)+K_{\mathrm{Iv}} \int_{0}^{t}\left(v_{\mathrm{Cd}}-v_{\mathrm{C}}\right) d \tau \\
\text { with } i_{\mathrm{L} 1 \mathrm{~d}}=i_{\mathrm{L} 2 \mathrm{~d}}=\left(p_{\mathrm{FCd}} / v_{\mathrm{FC}}\right) / 2,
\end{gathered}
$$

where $K_{\mathrm{Pv}}$ and $K_{\mathrm{Iv}}$ are the tuning proportional and integral gains, respectively. Next, to estimate the control signals $d_{1}$ and $d_{2}$, the conventional inner-loop PI current controllers are expressed as:

$$
\begin{aligned}
& d_{1}=K_{\mathrm{Pi} 1}\left(i_{\mathrm{L} 1 \mathrm{~d}}-i_{\mathrm{L} 1}\right)+K_{\mathrm{Ii} 1} \int_{0}^{t}\left(i_{\mathrm{L} 1 \mathrm{~d}}-i_{\mathrm{L} 1}\right) d \tau \\
& d_{2}=K_{\mathrm{Pi} 2}\left(i_{\mathrm{L} 2 \mathrm{~d}}-i_{\mathrm{L} 2}\right)+K_{\mathrm{I} 2} \int_{0}^{t}\left(i_{\mathrm{L} 2 \mathrm{~d}}-i_{\mathrm{L} 2}\right) d \tau
\end{aligned}
$$

where $K_{\mathrm{Pi} 1}, K_{\mathrm{Pi} 2}, K_{\mathrm{Ii} 1}$, and $K_{\mathrm{Ii} 2}$ are the tuning proportional and integral gains, respectively. Set $K_{\mathrm{Pi} 1}=K_{\mathrm{Pi} 2}=0.02 \mathrm{~A}^{-1}, K_{\mathrm{Ii} 1}=K_{\mathrm{Ii} 2}=20 \mathrm{~A} \cdot \mathrm{s}^{-1}, K_{\mathrm{Pv}}=35 \mathrm{~W} \cdot \mathrm{V}^{-1}$, and $K_{\mathrm{Iv}}=65,000 \mathrm{~W} \cdot \mathrm{V} \cdot \mathrm{s}^{-1}$. Figures 7 and 8 illustrate the dynamic response of the DC bus voltage stabilization with CRL and CPL disturbances using a linear controller and the studied controller. $\mathrm{CH} 1-\mathrm{CH} 4$ represent the input FC current $i_{\mathrm{FC}}$, disturbance load power $p_{\mathrm{CH}}$, first duty cycle $d_{1}$, and DC bus voltage $v_{C}$, respectively. For the first scenario CRL (Figure 7), the external load resistor is changed from 10.08 to $6.05 \Omega$ at $t=5 \mathrm{~ms}$; this indicates that the equilibrium point changes from 1.2 to $2 \mathrm{~kW}$, revealing that, using the proposed Hamiltonian controller, the DC bus voltage is regulated faster with a lower voltage deviation and lower setting time, leading to stronger robustness against CRLs. More importantly, for the second scenario CPL (Figure 8), the disturbance load power is stepped from 1.2 to $2 \mathrm{~kW}$ at $t=5 \mathrm{~ms}$. The performance of the cascaded PI algorithm is poorer than that of the proposed method, and the transient behavior of the PI method exhibits much worse performance, with a very large overshoot and oscillations. For the proposed control law in Figure 8b, the DC bus voltage undershoots when the power increases $7.27 \%(8 \mathrm{~V})$ and the associated settling time is $15 \mathrm{~ms}$. 


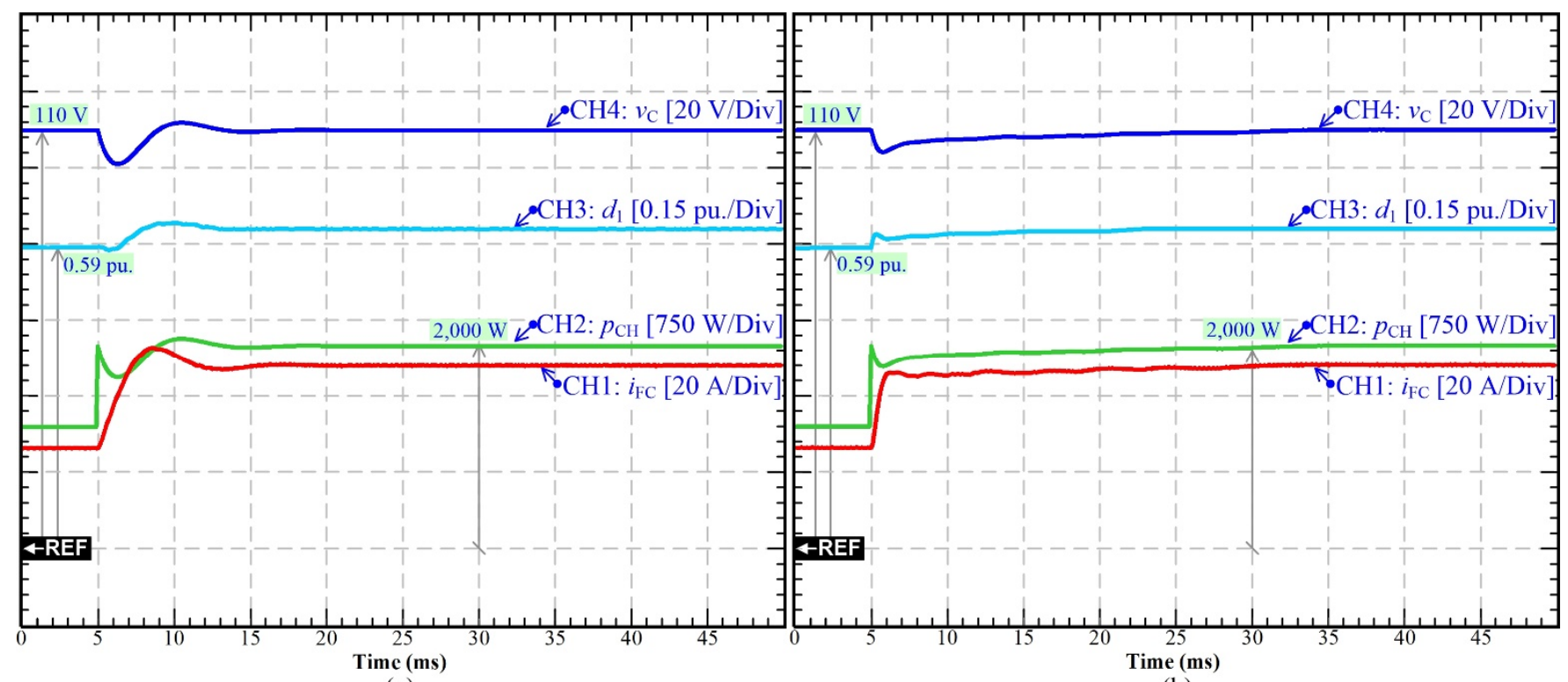

(a)

(b)

Figure 7. Simulation results: comparison of system dynamic response with CRL step from 10.08 to $6.05 \Omega$ : (a) cascaded linear PI controller (b) proposed controller.

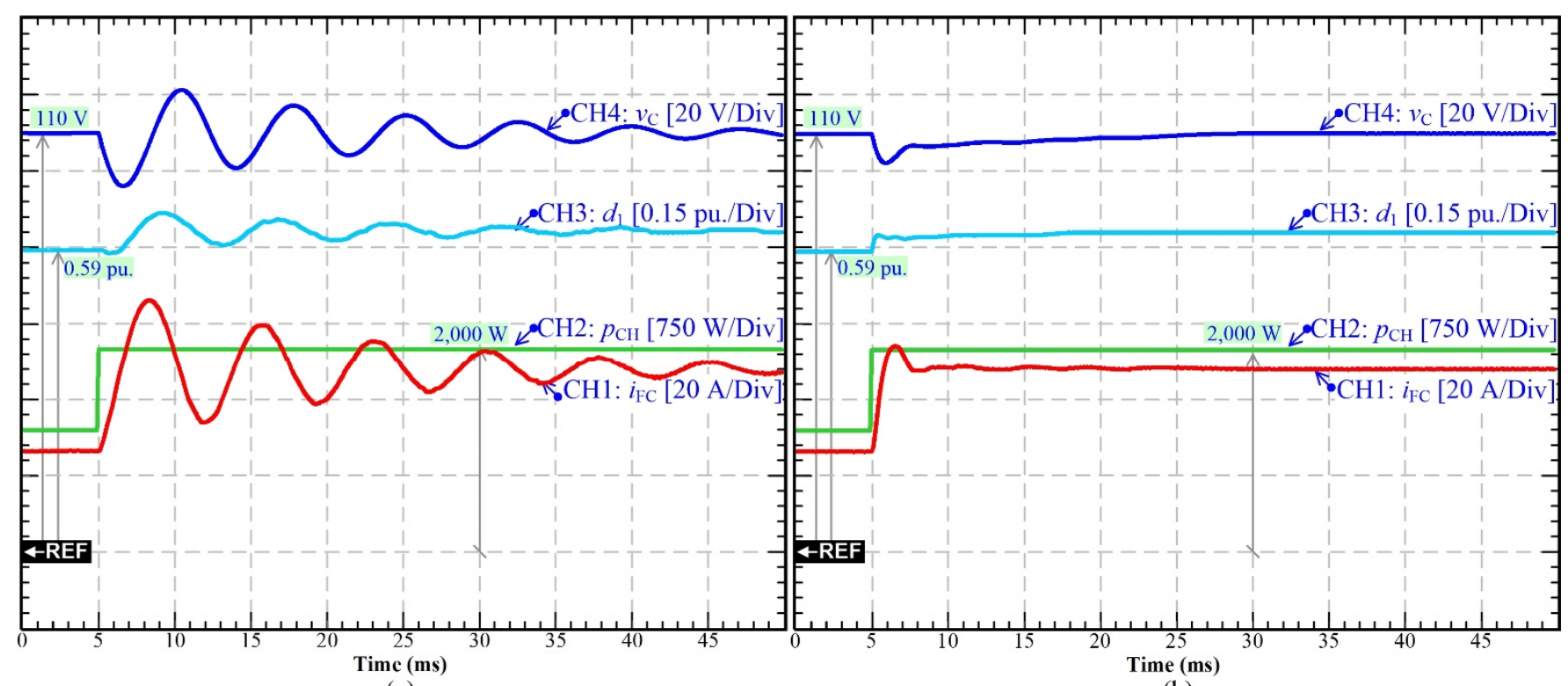

(a)

(b)

Figure 8. Simulation results: comparison of system dynamic response with CPL step $(1.2 \mathrm{~kW} \rightarrow 2 \mathrm{~kW})$ : (a) cascaded linear PI controller $(\mathbf{b})$ proposed controller.

\section{Conclusions}

This article reports the instability issues in DC microgrid networks, particularly those caused by the CPLs for parallel DC-DC boost power converters. To solve this issue, a new adaptive Hamiltonian energy control law (or a new IDA-PBC) is applied to stabilize the large oscillations caused by the CPLs in the DC distribution. To remove the static errors of the DC bus voltage level $\left(v_{C}=v_{C d}\right)$ and the two current sharing inductors $\left(i_{\mathrm{L} 1}=i_{\mathrm{L} 2}\right)$ caused by the system disturbances, noise, and modeling error, two integral terms are suggested in the proposed control law. The proposed controller provides superior DC bus voltage stabilization compared to the classic cascaded linear PI controller. The MATLAB simulation and experimental results (with a $2.5 \mathrm{~kW}$ FC converter supplied by the $\mathrm{PEMFC} /$ reformer) are presented to authenticate the control performance of the proposed 
controller. Furthermore, the experimental tests have revealed possible oxygen starvation through the decrease in the fuel cell stack voltage, due to large constant power load steps. Therefore, to avoid this phenomenon and the likely degradation of the fuel cell, mitigation strategies have to be developed by regulating the fuel cell current derivative.

Finally, the proposed adaptive Hamiltonian energy control law is a model-based control system. It is necessary to identify the controlled plant parameters (such as $r_{\mathrm{Ln}}$ ) to determine the port-Hamiltonian form. In future work, some real-time parameter observers will be studied to improve the control system.

Author Contributions: Conceptualization, B.N.-M. and S.P.; methodology, S.P. and D.G.; software, P.T.; validation, S.P. and D.G.; formal analysis, S.P.; investigation, P.T. and D.G.; resources, P.T.; data curation, P.M.; writing-original draft preparation, P.T.; writing-review and editing, D.G.; visualization, N.B.; supervision, B.N.-M.; project administration, N.B.; funding acquisition, P.T. All authors have read and agreed to the published version of the manuscript.

Funding: This work was funded by the International Research Partnerships: Electrical Engineering Thai-French Research Center (EE-TFRC) between the Université de Lorraine and King Mongkut's University of Technology North Bangkok through the Research Program Cooperation under Grant KMUTNB-64-KNOW-20. In addition, this work was partially supported by the French PIA project «Lorraine Université d'Excellence», reference ANR-15-IDEX-04-LUE.

Institutional Review Board Statement: Not applicable.

Informed Consent Statement: Not applicable.

Data Availability Statement: The data presented in this study are available on request from the corresponding authors. The data are not publicly available due to their current utilization for future works involving the authors of this paper.

Conflicts of Interest: The authors declare no conflict of interest.

\section{References}

1. Rezk, H.; Fathy, A. Performance Improvement of PEM Fuel Cell Using Variable Step-Size Incremental Resistance MPPT Technique. Sustainability 2020, 12, 5601. [CrossRef]

2. Wilberforce, T.; Olabi, A.G. Performance Prediction of Proton Exchange Membrane Fuel Cells (PEMFC) Using Adaptive Neuro Inference System (ANFIS). Sustainability 2020, 12, 4952. [CrossRef]

3. Thounthong, P.; Phattanasak, M.; Guilbert, D.; Takorabet, N.; Pierfederici, S.; Nahid-Mobarakeh, B.; Bizon, N.; Kumam, P. Differential Flatness Based-Control Strategy of a Two-Port Bidirectional Supercapacitor Converter for Hydrogen Mobility Applications. Energies 2020, 13, 2794. [CrossRef]

4. Thounthong, P.; Mungporn, P.; Guilbert, D.; Takorabet, N.; Pierfederici, S.; Nahid-Mobarakeh, B.; Hu, Y.; Bizon, N.; Huangfu, Y.; Kumam, P. Design and control of multiphase interleaved boost converters-based on differential flatness theory for PEM fuel cell multi-stack applications. Int. J. Electr. Power Energy Syst. 2021, 124, 106346. [CrossRef]

5. Zhuo, S.; Gaillard, A.; Li, Q.; Ma, R.; Paire, D.; Gao, F. Current Ripple Optimization of Four-Phase Floating Interleaved DC-DC Boost Converter Under Switch Fault. IEEE Trans. Ind. Appl. 2020, 56, 4214-4224. [CrossRef]

6. Thounthong, P. Port-Hamiltonian Formulation of Adaptive Hamiltonian PID controller to Solve Constant Power Load Stability Issue in DC Microgrid: Control of a Fuel Cell Converter. In Proceedings of the 2021 IEEE 12th Energy Conversion Congress \& Exposition-Asia (ECCE-Asia) 2021, Singapore, 24-27 May 2021.

7. Thounthong, P.; Nahid-Mobarakeh, B.; Pierfederici, S.; Mungporn, P.; Bizon, N.; Kumam, P. Hamiltonian Control Law Based on Lyapunov-Energy Function for Four-Phase Parallel Fuel Cell Boost Converter. In Proceedings of the 2020 International Conference on Power, Energy and Innovations (ICPEI), Chiang Mai, Thailand, 16-18 October 2020.

8. Thounthong, P.; Mungporn, P.; Pierfederici, S.; Guilbert, D.; Bizon, N. Adaptive Control of Fuel Cell Converter Based on a New Hamiltonian Energy Function for Stabilizing the DC Bus in DC Microgrid Applications. Mathematics 2020, 8, 2035. [CrossRef]

9. Naseri, F.; Farjah, E.; Kazemi, Z.; Schaltz, E.; Ghanbari, T.; Schanen, J. Dynamic Stabilization of DC Traction Systems Using a Supercapacitor-Based Active Stabilizer with Model Predictive Control. IEEE Trans. Transp. Electrif. 2020, 6, 228-240. [CrossRef]

10. Wu, Y.; Mahmud, M.; Zhao, Y.; Mantooth, H. Uncertainty and Disturbance Estimator-Based Robust Tracking Control for Dual-Active-Bridge Converters. IEEE Trans. Transp. Electrif. 2020, 6, 1791-1800. [CrossRef]

11. Glover, S.F.; Sudhoff, S.D. An experimentally validated nonlinear stabilizing control for power electronics based power systems. Soc. Automot. Eng. (SAE) J. 1998, 1, 981255.

12. Emadi, A.; Khaligh, A.; Rivetta, C.; Williamson, G. Constant Power Loads and Negative Impedance Instability in Automotive Systems: Definition, Modeling, Stability, and Control of Power Electronic Converters and Motor Drives. IEEE Trans. Veh. Technol. 2006, 55, 1112-1125. [CrossRef] 
13. Cespedes, M.; Xing, L.; Sun, J. Constant-Power Load System Stabilization by Passive Damping. IEEE Trans. Power Electron. 2011, 26, 1832-1836. [CrossRef]

14. Liu, S.; Su, P.; Zhang, L. A Virtual Negative Inductor Stabilizing Strategy for DC Microgrid with Constant Power Loads. IEEE Access 2018, 6, 59728-59741. [CrossRef]

15. You, J.; Fan, Z.; Hu, Y.; Deng, M. Virtual resistor based DBVC and active damping method for DC bus stabilization of cascaded power converters system. In Proceedings of the 2017 IEEE Transportation Electrification Conference and Expo, Asia-Pacific (ITEC Asia-Pacific) 2017, Harbin, China, 7-10 August 2017.

16. Lu, X.; Sun, K.; Guerrero, J.; Vasquez, J.; Huang, L.; Wang, J. Stability Enhancement Based on Virtual Impedance for DC Microgrids with Constant Power Loads. IEEE Trans. Smart Grid 2015, 6, 2770-2783. [CrossRef]

17. Mungporn, P.; Yodwong, B.; Thounthong, P.; Ekkaravarodome, C.; Bilsalam, A.; Nahid-Mobarakeh, B.; Pierfederici, S.; Guilbert, D.; Bizon, N.; Khomfoi, S.; et al. Study of Hamiltonian Energy Control of Multiphase Interleaved Fuel Cell Boost Converter. In Proceedings of the 2019 Research, Invention, and Innovation Congress (RI2C), Bangkok, Thailand, 11-13 December 2019.

18. Pang, S.; Nahid-Mobarakeh, B.; Pierfederici, S.; Phattanasak, M.; Huangfu, Y.; Luo, G.; Gao, F. Interconnection and Damping Assignment Passivity-Based Control Applied to On-Board DC-DC Power Converter System Supplying Constant Power Load. IEEE Trans. Ind. Appl. 2019, 55, 6476-6485. [CrossRef]

19. Ravada, B.; Tummuru, N. Control of a Supercapacitor-Battery-PV Based Stand-Alone DC-Microgrid. IEEE Trans. Energy Convers. 2020, 35, 1268-1277. [CrossRef]

20. Mungporn, P.; Thounthong, P.; Yodwong, B.; Ekkaravarodome, C.; Bilsalam, A.; Pierfederici, S.; Guilbert, D.; Nahid-Mobarakeh, B.; Bizon, N.; Shah, Z.; et al. Modeling and Control of Multiphase Interleaved Fuel-Cell Boost Converter Based on Hamiltonian Control Theory for Transportation Applications. IEEE Trans. Transp. Electrif. 2020, 6, 519-529. [CrossRef]

21. Ma, R.; Xu, L.; Xie, R.; Zhao, D.; Huangfu, Y.; Gao, F. Advanced Robustness Control of DC-DC Converter for Proton Exchange Membrane Fuel Cell Applications. IEEE Trans. Ind. Appl. 2019, 55, 6389-6400. [CrossRef]

22. Thammasiriroj, W.; Mungporn, P.; Nahid-Mobarakeh, B.; Pierfederici, S.; Bizon, N.; Thounthong, P. Comparative Study of Model-Based Control of Energy/Current Cascade Control for a Multiphase Interleaved Fuel Cell Boost Converter. In Proceedings of the 2020 International Conference on Power, Energy and Innovations (ICPEI), Chiang Mai, Thailand, 16-18 October 2020.

23. Ramos-Paja, C.; Giral, R.; Martinez-Salamero, L.; Romano, J.; Romero, A.; Spagnuolo, G. A PEM Fuel-Cell Model Featuring Oxygen-Excess-Ratio Estimation and Power-Electronics Interaction. IEEE Trans. Ind. Electron. 2010, 57, 1914-1924. [CrossRef]

24. Ramos-Paja, C.; Bordons, C.; Romero, A.; Giral, R.; Martinez-Salamero, L. Minimum Fuel Consumption Strategy for PEM Fuel Cells. IEEE Trans. Ind. Electron. 2009, 56, 685-696. [CrossRef]

25. Tang, X.; Wang, C.; Hu, Y.; Liu, Z.; Li, F. Adaptive Fuzzy PID Based on Granular Function for Proton Exchange Membrane Fuel Cell Oxygen Excess Ratio Control. Energies 2021, 14, 1140. [CrossRef]

26. Ramos-Paja, C.; Spagnuolo, G.; Petrone, G.; Mamarelis, E. A perturbation strategy for fuel consumption minimization in polymer electrolyte membrane fuel cells: Analysis, Design and FPGA implementation. Appl. Energy 2014, 119, 21-32. [CrossRef]

27. Thounthong, P.; Mungporn, P.; Pierfederici, S.; Guilbert, D.; Takorabet, N.; Nahid-Mobarakeh, B.; Hu, Y.; Bizon, N.; Huangfu, Y.; Kumam, P.; et al. Robust Hamiltonian Energy Control Based on Lyapunov Function for Four-Phase Parallel Fuel Cell Boost Converter for DC Microgrid Applications. IEEE Trans. Sustain. Energy 2021, 12, 1500-1511. [CrossRef]

28. Thounthong, P. Port-Hamiltonian Formulation of Adaptive PI Controller for Constant Power Load Stability Issue: Case Study for Multiphase Fuel Cell Converters. In Proceedings of the 2021 9th International Electrical Engineering Congress (iEECON), Pattaya, Thailand, 10-12 March 2021.

29. Cupelli, M.; Gurumurthy, S.; Bhanderi, S.; Yang, Z.; Joebges, P.; Monti, A.; De Doncker, R. Port Controlled Hamiltonian Modeling and IDA-PBC Control of Dual Active Bridge Converters for DC Microgrids. IEEE Trans. Ind. Electron. 2019, 66, 9065-9075. [CrossRef]

30. Pang, S.; Nahid-Mobarakeh, B.; Hashjin, S.; Pierfederici, S.; Martin, J.; Liu, Y.; Huangfu, Y.; Luo, G.; Gao, F. Stability Improvement of Cascaded Power Conversion Systems Based on Hamiltonian Energy Control Theory. IEEE Trans. Ind. Appl. 2021, 57, 1081-1093. [CrossRef]

31. Montoya, O.; Garces, A.; Avila-Becerril, S.; Espinosa-Perez, G.; Serra, F. Stability Analysis of Single-Phase Low-Voltage AC Microgrids with Constant Power Terminals. IEEE Trans. Circuits Syst. II Express Briefs 2019, 66, 1212-1216. [CrossRef]

32. Zhang, Z.; Qiao, W.; Hui, Q. Power System Stabilization Using Energy-Dissipating Hybrid Control. IEEE Trans. Power Syst. 2019, 34, 215-224. [CrossRef]

33. Harnefors, L.; Finger, R.; Wang, X.; Bai, H.; Blaabjerg, F. VSC Input-Admittance Modeling and Analysis above the Nyquist Frequency for Passivity-Based Stability Assessment. IEEE Trans. Ind. Electron. 2017, 64, 6362-6370. [CrossRef]

34. Harnefors, L.; Yepes, A.; Vidal, A.; Doval-Gandoy, J. Passivity-Based Controller Design of Grid-Connected VSCs for Prevention of Electrical Resonance Instability. IEEE Trans. Ind. Electron. 2015, 62, 702-710. [CrossRef] 
35. Sriprang, S.; Nahid-Mobarakeh, B.; Takorabet, N.; Pierfederici, S.; Bizon, N.; Kuman, P.; Thounthong, P. Permanent Magnet Synchronous Motor Dynamic Modeling with State Observer-based Parameter Estimation for AC Servomotor Drive Application. Appl. Sci. Eng. Prog. 2019, 12. [CrossRef]

36. Sriprang, S.; Nahid-Mobarakeh, B.; Takorabet, N.; Pierfederici, S.; Kumam, P.; Bizon, N.; Taghavi, N.; Vahedi, A.; Mungporn, P.; Thounthong, P. Design and control of permanent magnet assisted synchronous reluctance motor with copper loss minimization using MTPA. J. Electr. Eng. 2020, 71, 11-19. [CrossRef] 